\title{
No Adverse Effects of Lead on Renal Function in Lead-exposed Workers
}

\author{
Kazuyuki OMAE ${ }^{1)}$, Haruhiko SAKURAI', Toshiaki HIGASHI ${ }^{2}$, \\ Takashi MUTO"), Masaaki ICHIKAWA ${ }^{3)}$ \\ and Norihiro SASAKI ${ }^{3)}$
}

\author{
1) Department of Preventive Medicine and Public Health, School of Medicine, Keio University \\ 35 Shinanomachi, Shinjuku-ku, Tokyo 160, Japan \\ 2) Department of Health Policy and Management, University of Occupational and Environmental Health \\ 1-1 Iseigaoka, Yahatanishi-ku, Kitakyushu City, Fukuoka 807, Japan \\ 3) Japan Industrial Safety and Health Association, Occupational Health Research Center \\ 5-35-1, Shiba, Minato-ku, Tokyo 108, Japan
}

(Received January 29, 1990 and in revised form March 26, 1990)

\begin{abstract}
A cross-sectional study was performed on 165 male lead-exposed workers to clarify the quantitative relationships between less severe exposure to lead and its effects on renal function in 1985. Mean and range of blood lead concentration (Pb-B) were $36.5 \mu \mathrm{g}$ / dl and $6-73 \mu \mathrm{g} / \mathrm{dl}$, respectively. Duration of lead expusure was 0.1 to 26.3 years. No lead-related changes were detected in serum creatinine concentration, beta- 2 microgloburin in urine, creatinine clearance, beta-2 microgloburin clearance, and uric acid clearance. Twenty of the 165 workers had been exposed to lead for more than 10 years with mean duration of 21.0 years. Average concentrations of $\mathrm{Pb}-\mathrm{B}$ in each individual during 1972 to 1984 were $26.1-66.6 \mu \mathrm{g} / \mathrm{dl}$. Renal function indices of these 20 workers were not different from those of remaining lead-exposed workers whose lead exposure duration were 10 years or less. These results suggest that long-term less severe exposure to lead up to $70 \mu \mathrm{g} / \mathrm{dl}$ of $\mathbf{P b}-\mathbf{B}$ may not cause adverse effects on renal glomerular function and proximal tubular function.
\end{abstract}

Key words: Lead-Long-term exposure-Renal function-Cross-sectional study-Dose-effect relationship

The kidney is known to be one of the target organs in both acute and chronic lead poisoning. Acute massive exposure to lead induced renal proximal tubular dysfunction with Fanconi syndrome ${ }^{1,2)}$ and lead-containing intranuclear inclusion bodies in the proximal tubule cells. ${ }^{1,3-6)}$ Prolonged heavy exposure to lead caused progressive chronic nephropathy resulting in chronic renal failure and contracted kidney. ${ }^{7-12}$ Excess death from chronic renal disorders has also been reported in some worker population with long-term lead exposure. ${ }^{13,14)}$

However, the dose-effect relationship with regard to renal effect has remained unclear and controversial for long-term less severe exposure to lead ${ }^{15)}$. The 
purpose of this cross-sectional study in 1985 was to clarify the quantitative relationships between long-term less severe exposure to lead and its effects on renal function.

\section{SubJeCts AND Methods}

The number of lead-exposed workers surveyed was 192. All of them were male working in a lead storage battery manufacturing factory and had no past or present history of renal disease, diabetes mellitus or essential hypertension with or without administration of anti-hypertensive drugs.

Renal function was assessed by measuring serum creatitine concentration $(\mathrm{Cr}-\mathrm{S})$, creatinine clearance $(\mathrm{Cr}-\mathrm{C})$, beta-2 microgloburin in urine $\left(\beta_{2} \mathrm{MG}-\mathrm{U}\right)$, beta- 2 microglobulin clearance $\left(\beta_{2} \mathrm{MG}-\mathrm{C}\right)$, and uric acid clearance (UA-C).

Urine and venous blood were collected at the working place. All subjects were asked to drink $500 \mathrm{ml}$ of water and to urinate about 20 to $30 \mathrm{~min}$ later. About one hour later after the first urination, they were called again and urine and venous blood were collected for clearance study and determination of $\mathrm{Pb}-\mathrm{B}$, with the greatest caution taken agaitst lead contamination of samples. The renal clearance values were adjusted to the standard body surface area of $1.73 \mathrm{~m}^{2}$.

Whole blood was pretreated by the method of Stoeppler and Brandt, ${ }^{16)}$ and $\mathrm{Pb}-\mathrm{B}$ was measured by flameless atomic absorption spectrometry (Z-7000, Hitachi) under the internal quality control using pooled blood and control blood specimens (Control Blood for Metals 1, BEHRING INSTITUT). Serum and urinary beta- 2 microgluburiln were determited by enzyme immunoassay (Imzyne $\beta_{2}-\mathrm{M}$, FUJIREBIO).

Twenty-seven of the 192 subjects were excluded from statistical analysis because urinary flow rate between the first and second urination was $1 \mathrm{ml} / \mathrm{min}$ or less, even though $500 \mathrm{ml}$ water load method was strictly adhered to. Thus, number of lead-exposed workers analyzed was 165. Age of the 165 workers was 18.4-57.3 years and exposure length to lead was $0.1-26.3$ years.

Thirty-one of the 165 workers have been exposed to lead for more than 10 years. Determination of $\mathrm{Pb}-\mathrm{B}$ was carried out since 1972 by Hessel's method. ${ }^{17}$ However, because measurements of $\mathrm{Pb}-\mathrm{B}$ had been one of the secondary screening items until recent year, $\mathrm{Pb}-\mathrm{B}$ of 11 of the 31 long-term lead-exposed workers were measured only 3 times or less during the followed period. Thus, it was not appopriate to assess their past $\mathrm{Pb}-\mathrm{B}$ levels from available $\mathrm{Pb}-\mathrm{B}$ data and they were eliminated from the analysis of long-term lead effects on the renal function. $\mathrm{Pb}-\mathrm{B}$ of the 20 long-term lead-exposed workers analyzed been measured 5 to 20 times during 1972 to 1984 . Exposure duration to lead was 10.2 to 26.3 years with mean of 21.0 years, and age was 28.4 to 50.5 years, with mean of 41.7 years. 


\section{RESULTS}

Information from industrial physicians and nurses indicated that renal dysfunction probably due to excess exposure to lead have not be seen at least for the last decace, and all hypertensive employees eliminated from the study did not show any signs of renal dysfunction from data of periodical health examinations performed at the interval of 6 months.

Concentrations of $\mathrm{Cr}-\mathrm{S}$ and $\mathrm{Pb}-\mathrm{B}$ in 27 workers eliminated from statistical analysis because of small amount of urinary flow rate were not different from the 165 workers analyzed.

Table 1. Comparison of renal function indices by $\mathbf{P b}-\mathbf{B}$ levels.

\begin{tabular}{ccccccc}
\hline $\begin{array}{c}\mathrm{Pb}-\mathrm{B} \\
(\mu \mathrm{g} / \mathrm{dl})\end{array}$ & $\mathrm{n}$ & $\begin{array}{c}\mathrm{Cr}-\mathrm{S} \\
(\mathrm{mg} / \mathrm{dl})\end{array}$ & $\begin{array}{c}\mathrm{Cr}-\mathrm{C} \\
(\mathrm{ml} / \mathrm{min})\end{array}$ & $\begin{array}{c}\beta_{2} \mathrm{MG}-\mathrm{U} \\
(\mu \mathrm{g} / \mathrm{l})\end{array}$ & $\begin{array}{c}\beta_{2} \mathrm{MG}-\mathrm{C} \\
(\mu 1 / \mathrm{min})\end{array}$ & $\begin{array}{c}\mathrm{UA}-\mathrm{C} \\
(\mathrm{ml} / \mathrm{min})\end{array}$ \\
\hline-19 & 21 & $1.00(1.13)$ & $99.3(1.12)$ & $12.3(2.49)-$ & $47.4(1.80)$ & $7.60(1.39)$ \\
$20-29$ & 39 & $0.96(1.11)$ & $105.4(1.13)$ & $16.9(2.48) *$ & $52.1(1.88)$ & $8.58(1.55)$ \\
$30-39$ & 34 & $0.96(1.14)$ & $104.5(1.11) *$ & $23.1(2.59)$ & $57.9(1.94)$ & $9.02(1.47)$ \\
$40-49$ & 36 & $0.95(1.13)$ & $105.3(1.14)$ & $19.3(3.13)$ & $56.2(1.92)$ & $8.47(1.49)$ \\
$50-59$ & 25 & $0.93(1.10)$ & $110.1(1.12)-$ & $14.8(2.81)$ & $44.6(1.76)$ & $8.34(1.29)$ \\
$60-$ & 10 & $0.97(1.12)$ & $102.2(1.18)$ & $14.7(3.09)$ & $38.2(1.78)$ & $7.68(1.60)$ \\
\hline
\end{tabular}

Geometric mean and geometric standard deviation. *: $\mathrm{p}<0.05$

Abbreviations: See text.

Table 2. Partial correlation coefficients between $\mathbf{P b}-\mathbf{B}$ and renal clearance indices keeping some effective variables on clearance constant.*

\begin{tabular}{cccc}
\hline & $\mathrm{Cr}-\mathrm{C}$ & $\beta_{2} \mathrm{MG}-\mathrm{C}$ & $\mathrm{UA}-\mathrm{C}$ \\
\hline $\mathrm{Pb}-\mathrm{B}$ & 0.042 & -0.053 & -0.011 \\
\hline
\end{tabular}

*: See text.

Table 3. Renal function indices in long-term and short-term lead-exposed workers.

\begin{tabular}{llrr}
\hline & & \multicolumn{2}{c}{ Exposure duration to lead $($ Ex-D) } \\
\cline { 3 - 4 } & & $>10$ years $(\mathrm{n}=20)$ & $<10$ years $(\mathrm{n}=134)$ \\
\hline $\mathrm{Ex}-\mathrm{D}$ & (mean, range) & $21.0(10.2-26.3)^{* *}$ & $4.6(0.1-7.4)$ \\
$\mathrm{Age}$ & (mean, range) & $41.7(28.4-50.5)^{* *}$ & $32.9(18.4-57.3)$ \\
$\mathrm{Pb}-\mathrm{B}$ & (mean, range) & $\left.43.7(2)^{*}-73\right)^{*}$ & $36.2(6-73)$ \\
& & & \\
$\mathrm{Cr}-\mathrm{S}$ & $(\mathrm{GM}$, range) & $0.59(0.76-1.14)$ & $0.96(0.68-1.41)$ \\
$\mathrm{Cr}-\mathrm{C}$ & $(\mathrm{GM}$, range) & $103.4(84.5-134.1)$ & $105.6(74.7-149.7)$ \\
$\beta_{2} \mathrm{MG}-\mathrm{U}$ (GM, range) & $18.1(6.5-167.7)$ & $17.2(4.1-137.1)$ \\
$\beta_{2} \mathrm{MG}-\mathrm{C}$ (GM, range) & $50.55(13.8-333.0)$ & $52.10(15.2-359.4)$ \\
$\mathrm{UA}-\mathrm{C}$ & $(\mathrm{GM}$, range) & $8.98(1.86-21.93)$ & $8.43(2.24-20.93)$
\end{tabular}

*,**: $\mathrm{p}<0.05,0.01$ between the two groups. GM: Geometric mean. 


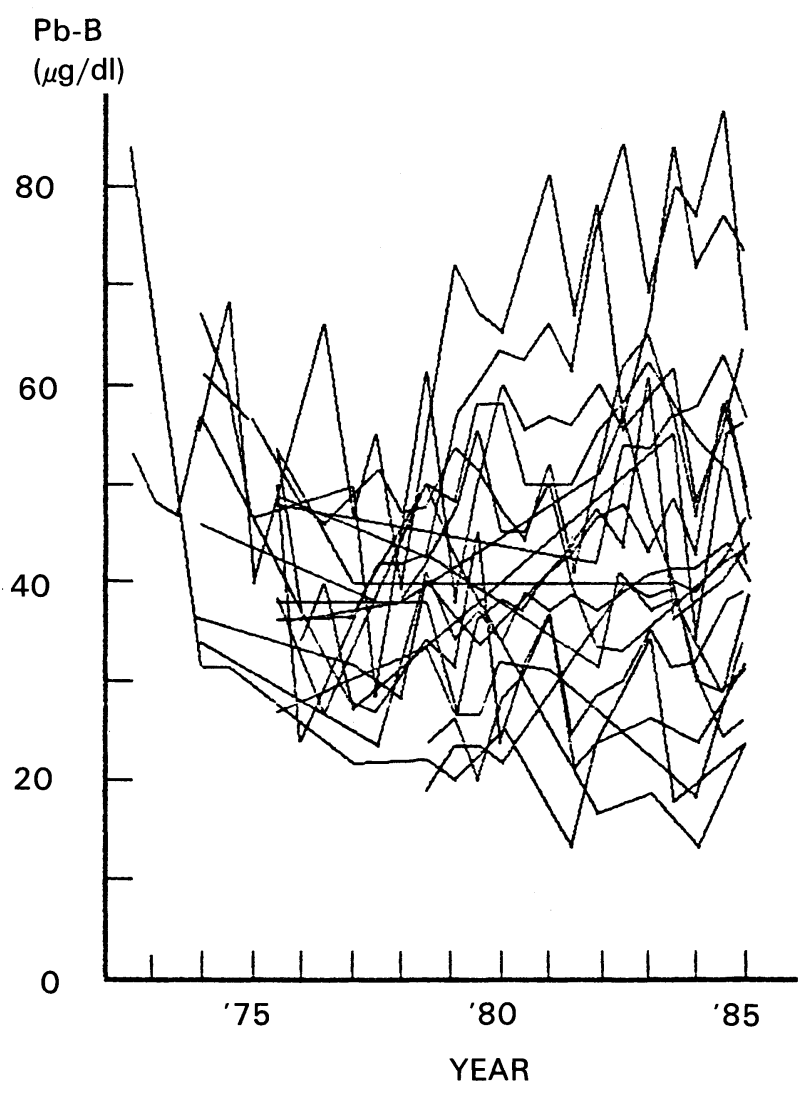

Fig. 1. Chronological change of $\mathrm{Pb}-\mathrm{B}$ in the long-term lead-exposed workers.

$\mathrm{Pb}-\mathrm{B}$ of the 165 workers was 6 to $73 \mu \mathrm{g} / \mathrm{dl}$ with mean of $36.5 \mu \mathrm{g} / \mathrm{dl}$. Table 1 shows renal function indices categorized by $\mathrm{Pb}-\mathrm{B}$ levels. Significant differences between the categorized groups were found sporadically but dose-effect relationships were not clear.

Table 2 shows partial correlation coefficients between $\mathrm{Pb}-\mathrm{B}$ and renal clearance indices keeping age, urinary flow rate, serum concentration of the pertinent substances constant and, in cases of $\beta_{2}$ MG-C and UA-C, glomerular filtration rate (GFR, Cr-C was substituted.) constant. No informative correlation was observed.

Figure 1 illustrates the chronological changes of $\mathrm{Pb}-\mathrm{B}$ of the 20 long-term lead-exposed workers. Average concentration of $\mathrm{Pb}-\mathrm{B}$ calculated from available data during 1972 to 1984 in each individual was 26.1 to $66.6 \mu \mathrm{g} / \mathrm{dl}$, and maximal concentration in each individoal ranged from 34 to $87 \mu \mathrm{g} / \mathrm{dl}$, respectively. $\mathrm{Pb}-\mathrm{B}$ in 1985 were not exceptional in comparison with past levels.

Table 3 shows mean and range of age, exposure length to lead, $\mathrm{Pb}-\mathrm{B}$, and 
Table 4. $\%$-predicted values of the renal function indices.

\begin{tabular}{lccc}
\hline & \multicolumn{3}{c}{ Exposure duration to lead $($ Ex-D) } \\
\cline { 2 - 4 } & $>10$ years $(\mathrm{n}=20)$ & $<10$ years $(\mathrm{n}=134)$ \\
\hline$\% \mathrm{Cr}-\mathrm{C} \quad$ (mean, SD) & $99.73(2.02)$ & $100.00(2.09)$ \\
$\% \beta_{2} \mathrm{MG}-\mathrm{C}($ mean, SD) & $100.84(19.73)$ & $100.00(14.24)$ \\
$\% \mathrm{UA}-\mathrm{C} \quad$ (mean, SD) & $106.89(23.87)$ & $100.00(14.74)$ \\
\hline
\end{tabular}

renal function indices in the 20 long-term lead-exposed workers and short-term lead-exposed workers whose exposure length was less than 10 years. Age was significantly older and $\mathrm{Pb}-\mathrm{B}$ was significantly higher in the 20 long-term leadexposed workers, but the renal function indices were not different between the two groups.

To adjust the effects of aging, urinary volume and, in cases of $\beta_{2} \mathrm{MG}-\mathrm{C}$ and UA-C, GFR, prediction equations for the renal function indices were calculated from the data of the 134 short-term lead-exposed workers by linear multiple regression procedure, and \%-predicted vaues of the renal function indices in the 20 long-term lead-exposed workers were assessed. Table 4 shows the \%-predicted values of the renal clearance indices. No differences were found between two groups.

Means of the \%-predicted values of renal clearance indices in the 11 long-term lead-exposed workers eliminated from the analysis were $99.05 \%(\mathrm{sd}=1.93)$ in $\mathrm{Cr}-\mathrm{C}, 99.97 \%(\mathrm{sd}=12.38)$ in UA-C, and $101.14 \%(\mathrm{sd}=17.43)$ in $\beta_{2} \mathrm{MG}-\mathrm{C}$. These values were not different from those in the 20 long-term lead-exposed workers analyzed.

\section{Discussion}

At most working sites of the factories surveyed, current environmental lead levels were below $0.1 \mathrm{mg} / \mathrm{m}^{3}$, the recommended occupational exposure limit by the Japan Association of Industrial Health, ${ }^{18)}$ but in some areas they exceeded the recommended limit resulting in the rather wide range of $\mathrm{Pb}-\mathrm{B}$. Though exact past environmental levels of lead could not be determined, the past and present $\mathrm{Pb}-\mathrm{B}$ levels in the 20 long-term lead-exposed subjects suggested that they should have been similar to the present ones.

Neither $\mathrm{Cr}-\mathrm{S}$ nor $\mathrm{Cr}-\mathrm{C}$ showed any noticeable relationships with $\mathrm{Pb}-\mathrm{B}$ in the cross-sectional observation. Results of $\mathrm{Cr}-\mathrm{S}$ and $\mathrm{Cr}-\mathrm{C}$ of the long-term leadexposed workers also indicated that renal glomerular function was not affected by long-term less severe exposure to lead.

Some authors reported the effects of lead on renal function in low- or middle-level exposure to lead. Hammond et al. ${ }^{19)}$ found that serum urea nitrogen in secondary lead smelter workers was correlated with lead exposure indices with 
$\mathrm{Pb}-\mathrm{B}$ of 25 to $101 \mu \mathrm{g} / \mathrm{d}$. Yamamura et al. $^{20)}$ reported that blood urea nitrogen (BUN) was increased in 4 of 15 male lead-exposed Shippoh-yaki (Japanese cloisonne) workers whose $\mathrm{Pb}-\mathrm{B}$ was 70 to $147 \mu \mathrm{g} / \mathrm{dl}$, but serum creatinine concentrations were within the normal range. Hong et al. ${ }^{21)}$ stated that routine clinical tests such as BUN and Cr-S were not sufficiently sensitive to detect the early effects of lead but that GFR was decreased in lead-exposed workers with 34 to $110 \mu \mathrm{g} / \mathrm{dl} \mathrm{Pb}-\mathrm{B}$. On the other hand, Buched et al. ${ }^{22)}$ reported that $\mathrm{Cr}-\mathrm{C}$ in 25 lead-exposed workers whose $\mathrm{Pb}-\mathrm{B}$ were $62 \mu \mathrm{g} / 100 \mathrm{ml}$ or below was normal, Pocuck et al. ${ }^{23)}$ found that $\mathrm{Pb}-\mathrm{B}$ did not have any relation with $\mathrm{Cr}-\mathrm{S}$ and Greenberg et al $^{24)}$ reported that $\mathrm{Cr}-\mathrm{C}$ in 38 workers whose $\mathrm{Pb}-\mathrm{B}$ ranged from 9 to $60 \mu \mathrm{g} / \mathrm{dl}$ was not correlated with $\mathrm{Pb}-\mathrm{B}$.

The lack of increased $\beta_{2} \mathrm{MG}-\mathrm{U}, \beta_{2} \mathrm{MG}-\mathrm{C}$ indicates that renal reabsorptional function for these glomerular filtrable substances at the level proximal tubular cells was not affected by lead. Buchet et al. ${ }^{22}$ reported that $\beta_{2} \mathrm{MG}-\mathrm{U}$ and $\beta_{2}$ MG-C in 25 workers with $\mathrm{Pb}-\mathrm{B}$ of $62 \mu \mathrm{g} / 100 \mathrm{ml}$ or below were normal. Vacca et al $^{25)}$ concluded that tubular proteinuria including beta- 2 microglobulinuria was not an early manifestation of toxicity of lead exposure from data of 7 leadexposed workers whose $\mathrm{Pb}-\mathrm{B}$ ranged from 83.5 to $390 \mu \mathrm{g} / \mathrm{dl}$ and who had been exposed to lead for at least 5 years. Greenberg et al. ${ }^{24)}$ suggested that there was no direct relationship between low levels of lead exposure and urate metabolism. On the other hand, Hong et al. ${ }^{21}$ suggested that decrease of tubular reabsorptive capacity for glucose was related to lead exposure.

In conclusion, adverse effects on function of glomerular filtration and tubular reabsorption of microglobulin and urate may not be induced by lead exposure when the level of $\mathrm{Pb}-\mathrm{B}$ is controlled up to $70 \mu \mathrm{g} / \mathrm{dl}$.

\section{REFERENCES}

1) Bennette WM. Lead nephropathy. Kidney Int 1985; $28: 212-20$.

2) Wilson RP, Thomson ML, Dent CE. Aminoaciduria in lead poisoning; case in childhood. Lancet $1953 ; 2: 66-8$.

3) Choie DD, Richter GM. Lead poisoning: Rapid formation of intranuclear inclusions. Science 1972; 177: 1194-5.

4) Choie DD, Richter GM. Effects of lead on the kidney. In: Singhal RL, Thomas JA, eds. Lead Toxicity. Baltimore-Munch: Urban \& Schwarzenberg, 1980.

5) Mistry P, Lucier GM, and Fowler AB. High-affinity lead binding proteins in rat kidney cytosol mediate cell-free nuclear translocation of lead. J Pharmacol Exp Ther 1980; 232: 462-9.

6) Oskarsson A and Fowler BA. Effects of lead inclusion bodies on subcellular distribution of lead in rat kidney: The relationship to mitochondrial function. Exp Molecul Pathol 1985; 43: 397408.

7) Batuman V, Landy E, Maesaka JK, et al. Contribution of lead to hypertension with renal impairment. N Engl J Med 1983; 309: 17-21.

8) Campbell BC, Beattie AD, Moor MR, et al. Renal insufficienty associated with excessive lead exposure. Brit Med J 1977; 19: 482-5.

9) Emerson BT: Chronic lead nephropathy. Kid Int 1973; 4: 1-5.

10) Goyer RA. Lead-induced nephrosclerosis. J UOEH 1982; suppl 4: 187-94. 
11) Henderson DA. Chronic nephritis in Queensland. Aust Ann Med 1955; 4: 163-77.

12) Weeden RP, Mallik DK, Batuman V. Detection and Treatment of Occupatiotal Lead Nephropathy. Arch Intern Med 1979; 139: 53-7.

13) Cooper CC and Graffey WR. Mortality of Lead Workers. JOM 1975; 17: 100-7.

14) Malcolm D, Barnett HAR. A mortality study of lead workers 1925-76. Brit J Ind Med 1982; 39: 404-10.

15) WHO. Environmental Health Criteria 3. Lead. 1977; WHO Geneva.

16) Stoeppler M, Brandt K. Contributions to automated trace analysis. Part II. Rapid method for the automated determination of lead in whole blood by electrothermal atomic-absorption spectrophotometry. Analyst 1978; 103: 714-22.

17) Hessel DW. A simple and rapid quantitative determination of lead in blood. Atomic Absorption Newsletter 1968; 7: 55-6.

18) Japan Association of Industrial Health. Recommendation of Permissible Exposure Limit. Jpn J Ind Health 1989; 31: 261 (In Japanese).

19) Hammond PB, Lerner SI,Gartside PS, et al. The relationship of biological indices of lead exposure to the health status of workers in a secondary lead smelter. JOM 1980; 22:475-84.

20) Yamamura Y, Yoshida M, Arai F, et al. A survey on health hazards of lead exposure in Shippo-yaki (Japanese cloisonne ware) workers. Jpn J Ind Health 1986; 28: 36-7 (In Japanese).

21) Hong CD, Hanenson IB, Lerner S, et al. Occupational exposure to lead: Effects on renal function. Kidney Int 1980: 489-94.

22) Buchet JP, Roels H, Bernard A, Lauwerys R. Assessment of renal function of workers exposed to inorganic lead, cadmium or mercury vapor. JOM 1980; 22: 741-50.

23) Pocock SJ, Shaper AG, Ashby D, et al. Blood lead concentration, blood pressure, and renal function. Brit Med J 1947; 289 : 872-4.

24) Greenberg A, Parkinson DK, Fetterolf DE, et al. Effects of elevated lead and cadmium burdens on renal function and calcium metabolism. Arch Environ Health 1986; 41: 69-76.

25) Vacca CV, Hines JD, Hall III PW. The proteinuria of industrial lead intoxication. Environ Res $1986 ; 41: 440-6$. 